\title{
KEUNTUNGAN MAKSIMUM DAN SKALA USAHA SUB SEKTOR KEHUTANAN: SUATU UPAYA PENINGKATAN PRODUKTIVITAS USAHA PERSUTERAAN ALAM DALAM PERSPEKTIF PEMBANGUNAN EKONOMI
}

\author{
Nurdiana $^{1}$, Muhammad Hasan ${ }^{2}$, Nuraisyiah ${ }^{3}$ \\ ${ }^{1}$ Pendidikan Ekonomi Universitas Negeri Makassar \\ Email: diana@unm.ac.id \\ ${ }^{2}$ Pendidikan Ekonomi Universitas Negeri Makassar \\ Email:m.hasan@unm.ac.id \\ ${ }^{3}$ Pendidikan Akuntansi Universitas Negeri makassar \\ Email: nuraisyiah@unm.ac.id
}

\begin{abstract}
This study aims to assess the economic feasibility of natural business enterprises in Enrekang Regency in terms of income or business profits. This research is quantitative research. The results of this study indicate that the business scale of natural business enterprises in Enrekang Regency is not in constant returns to scale conditions, so that means that the utilization of resources or factors of production in natural business enterprises in Enrekang Regency can still be improved or developed.
\end{abstract}

Keywords: Economic feasibility and natural business enterprises

\begin{abstract}
Abstrak. Penelitian ini bertujuan untuk mengkaji kelayakan ekonomi usaha persuteraan alam di Kabupaten Enrekang dilihat dari segi pendapatan atau keuntungan usaha tersebut. Penelitian ini adalah penelitian kuantitatif. Hasil penelitian ini menunjukan bahwa skala usaha pada usaha persuteraan alam di Kabupaten Enrekang tidak berada pada kondisi constant returns to scale, sehingga hal tersebut berarti bahwa pemanfaatan sumberdaya atau faktor produksi pada usaha persuteraan alam di Kabupaten Enrekang masih dapat ditingkatkan atau dikembangkan.
\end{abstract}

Kata kunci: Kelayakan ekonomi, usaha persuteraan alam

\section{PENDAHULUAN}

Jauh sebelum Johnston dan Mellor (1961) mengidentifikasi apa yang saat ini dianggap sebagai kontribusi ekonomi mendasar dari sektor pertanian untuk pembangunan, para ekonom berfokus pada bagaimana pertanian dapat memberikan kontribusi terbaik untuk pertumbuhan dan moderasi secara keseluruhan. Kajian-kajian yang dilakukan sebelumnya (Rosenstein-Rodan, 1943; Lewis, 1954; Scitovsky, 1954; Hirschman, 1958; Jorgenson, 1961; Fei dan Ranis, 1961; Hasan, 2013; Hasan dan Azis, 2018) menyoroti pertanian untuk banyak sumber daya dan kemampuan untuk mentransfer surplus ke yang lebih penting sektor industri.

Negara dengan kondisi perekonomian sedang berkembang secara umum digambarkan sebagai negara yang memiliki perekonomian ganda dengan sektor pertanian tradisional dan sektor modern (Cypher dan Dietz, 2008; Diao et al., 2006; Barrett et al., 2010; Tahir dan Hasan,
2018). Produktivitas diasumsikan lebih rendah di sektor pertanian daripada di sektor modern. Model tersebut diajukan oleh Lewis (1954) dan kemudian dilanjutkan oleh Ranis dan Fei (1961). Model Lewis terletak pada gagasan terjadi surplus tenaga kerja di sektor pertanian. Dengan produktivitas yang lebih rendah di bidang pertanian, upah akan lebih tinggi di sektor modern, yang mendorong tenaga kerja untuk berpindah dari pertanian ke sektor modern, yang pada gilirannya menghasilkan pertumbuhan ekonomi. Hasil kajian lainnya, seperti Schultz (1964), juga menunjukkan pentingnya pasokan pangan oleh sektor pertanian. Dalam pandangan Schultz (1964), pertanian penting bagi pertumbuhan ekonomi dalam arti bahwa ia menjamin subsistensi bagi masyarakat, tanpanya pertumbuhan tidak mungkin. Pandangan awal tentang peran pertanian dalam ekonomi ini sesuai dengan pengamatan empiris Kuznets (1966) bahwa pentingnya sektor pertanian semakin menurun seiring dengan perkembangan ekonomi. 
Dalam pandangan ini, peran pertanian dalam pembangunan ekonomi adalah menyediakan makanan murah dan upah rendah ke sektor modern. Jika tidak, kedua sektor memiliki beberapa interkoneksi. Pertumbuhan dan produktivitas yang lebih tinggi di sektor pertanian dapat berkontribusi terhadap pertumbuhan ekonomi secara keseluruhan dengan melepaskan tenaga kerja serta modal ke sektor-sektor lain dalam perekonomian. Namun, industrialisasi dilihat sebagai kekuatan pendorong utama di balik pembangunan dan pertanian suatu negara sebagai sektor produktivitas rendah tradisional.

Salah satu bagian dari sektor pertanian adalah subsektor kehutanan. Persuteraan alam sebagai salah satu kegiatan agribisnis dengan rangkaian usaha yang cukup panjang menjadi bagian dari pengembangan di bidang kehutanan yang dikaitkan dengan kegiatan agroindustri. Selain itu, kegiatan ini sudah lama dikenal dan dibudidayakan oleh sebagian masyarakat Indonesia terutama di daerah-daerah dengan lingkungan sosial budaya yang mendukung kegiatan tersebut seperti Sulawesi Selatan dan Jawa Barat.

Menurut Atmosoedarjo et al. (2000), untuk memenuhi kebutuhan kokon maka kita harus tetap impor dari Brazil, Turki, Cina, serta Uzbekistan sebagai sentra produksi sutera dunia. Permintaan di dalam negeri akan barang yang terbuat dari benang sutera sangat tinggi, sedangkan perkembangan produksi kokon di beberapa sentra produksi selalu tidak menentu. Situasi ini dihadapi juga oleh usaha persuteraan alam yang terdapat di Propinsi Sulawesi Selatan.

Tidak jarang petani sutera alam meninggalkan usaha tani sutera dan beralih pada komoditas lain yang dianggap lebih menguntungkan. Masalah yang dihadapi seperti, keterbatasan modal, aspek sumberdaya maupun sarana dan prasarana yang belum optimal perlu diatasi mengingat potensi wilayah yang mendukung serta peluang pasar yang masih terbuka.

Persuteraan alam di Kabupaten Enrekang dapat dikatakan memiliki keunggulan absolut dan keunggulan komparatif (Hasan, 2012; Hasan, 2013; Hasan, 2014). Keunggulan absolute diperoleh karena di Pulau Sulawesi hanya terdapat di Propinsi Sulawesi Selatan inilah adanya sentra produksi dan industri persuteraan alam mulai dari hulu hingga hilir. Keunggulan komparatif diperoleh karena di kedua daerah tersebut memiliki sumber daya alam dan sumber daya manusia yang mendukung. Secara umum proses produksinya merupakan (memiliki keunggulan karena kekayaan sumber daya alamnya) dan (memiliki keunggulan karena sumber daya manusia/tenaga kerja yang murah dan mampu mengoperasikan teknologi rendah).

Akan tetapi produknya belum memiliki keunggulan kompetitif karena kualitas produk dan kontinyuitas produksinya belum memenuhi standar konsumen global. Dinamika produksi sutera alam di Kabupaten Enrekang dalam empat tahun terakhir ini mengalami penurunan yang signifikan dalam kuantitas maupun kualitas.

\section{METODE PENELITIAN}

Penelitian ini adalah penelitian kuantitatif. Berdasarkan dari permasalahan dan tujuan penelitian, maka penelitian ini akan mengkaji kelayakan ekonomi usaha persuteraan alam melalui fungsi keuntungan petani pada usaha persuteraan alam di Kabupaten Enrekang. Berdasarkan tujuan yang hendak dicapai dalam penelitian ini, maka ditetapkan Kabupaten Enrekang sebagai salah satu basis usaha persuteraan alam di Propinsi Sulawesi Selatan. wilayah sampel penelitian adalah Kecamatan Alla dengan 55 responden petani yang layak untuk menjadi responden penelitian

Pengujian terhadap tercapai tidaknya keuntungan maksimal jangka pendek dilakukan dengan membandingkan parameter masingmasing perubah (variabel) dari fungsi produksi $(\beta)$ dengan parameter masing-masing fungsi permintaan input variabel $(\beta 1)$. Keuntungan maksimal jangka pendek akan tercapai jika $\beta=\beta 1$ untuk semua variabel. Dengan demikian bentuk pencapaian keuntungan maksimal jangka pendek adalah : Ho : $\beta \mathrm{i}=\beta \mathrm{il}(\mathrm{i}=1,2,3,4)$. Jika ada salah satu Ho yang ditolak, maka usaha tani produk tidak dapat mencapai keuntungan maksimum dalam jangka pendek (short-run) profit (Hasan dan Munarfah, 2009).

Pengujian skala usaha dilakukan terhadap besarnya nilai $\mathrm{k}$ atau $\Sigma \beta * j$. Apabila $\Sigma \beta * j$ $=1$ maka terjadi skala usaha tetap (CRS). Skala usaha menaik (IRS) terjadi apabila $\Sigma \beta * j>1$, dan skala usaha menurun apabila $\Sigma \beta * j<1$. Dengan demikian pengujian skala usaha dapat dirumuskan menjadi berikut:

Ho $: \Sigma \beta^{*} j=1$ (CRS)

Ha $: \Sigma \beta * j \neq 1$ (IRS/DRS)

Adapun pengujiannya memakai F-Test yaitu:

$\mathrm{F}$ hitung $<\mathrm{F}$ tabel, maka Ho diterima F hitung $>$ F tabel, maka Ho ditolak 


\section{HASIL DAN PEMBAHASAN}

Banyaknya input yang diminta produsen tergantung besarnya output yang direncanakan untuk diproduksi. Besarnya output yang diproduksi tergantung perhitungan mengenai tingkat output mana yang menghasilkan keuntungan maksimum. Berdasarkan teori tersebut, maka tidak mengherankan jika keuntungan maksimum menjadi tujuan utama bagi setiap pengusaha atau produsen, tcrmasuk pepersuteraan alam sebagai produsen di daerah penelitian. Sesuai dengan tujuan penelitian yang pertama sekaligus menguji hipotesis pertama yang menyatakan alokasi penggunaan faktorfaktor produksi belum optimal seluruhnya dan keuntungan maksimum belum tercapai.

Maka pengujian keuntungan maksimum jangka pendek ini bertujuan untuk mengetahui apakah usaha persuteraan alam yang terdapat di Kabupaten Enrekang telah mencapai keuntungan maksimum atau belum. Pengujian dilakukan dua cara yaitu pengujian serentak terhadap semua input variabel dan pengujian parsial terhadap masing-masing; input variabel. Hasil pengujian disajikan pada Tabel 1 berikut ini:

Tabel 1. Pengujian keuntungan maksimum

\begin{tabular}{|c|c|c|c|c|c|c|}
\hline \multirow{2}{*}{$\begin{array}{l}\text { Hipotesis } \\
\text { Nol }\end{array}$} & \multirow{2}{*}{$\begin{array}{l}\text { Hipotesis } \\
\text { Alternatif }\end{array}$} & \multirow{2}{*}{ Pengujian } & \multirow{2}{*}{$\begin{array}{c}\text { F } \\
\text { Hitung }\end{array}$} & \multicolumn{2}{|c|}{ F Tabel } & \multirow{2}{*}{ Keputusan } \\
\hline & & & & 0,01 & 0,05 & \\
\hline$\alpha i^{*}=\alpha i * ”$ & $\alpha i^{*} \neq \alpha i * ”$ & $\begin{array}{l}\text { Keuntungan } \\
\text { maksimum serentak }\end{array}$ & 121,51 & 3,48 & 2,45 & $\begin{array}{l}\text { Tolak Ho } \\
(\mathrm{P}: 0,0000)\end{array}$ \\
\hline$\alpha i^{*}=\alpha 2 *$ & $\alpha i^{*} \neq \alpha 1 *$ & $\begin{array}{l}\text { Alokasi optimum } \\
\text { tenaga kerja }\end{array}$ & 0,002 & 6,85 & 3,92 & $\begin{array}{l}\text { Terima Ho } \\
\text { (P:0,9557) }\end{array}$ \\
\hline$\alpha 2^{*}=\alpha 2 *$ & $\alpha i^{*} \neq \alpha 2 *$ & $\begin{array}{l}\text { Alokasi optimum } \\
\text { bibit }\end{array}$ & 140,16 & 6,85 & 3,92 & $\begin{array}{l}\text { Tolak Ho } \\
\text { (P:0,0000) }\end{array}$ \\
\hline$\alpha 3^{*}=\alpha 3 * "$ & $\alpha i^{*} \neq \alpha 3 *$ & $\begin{array}{l}\text { Alokasi optimum } \\
\text { pupuk }\end{array}$ & 2,568 & 6,85 & 3,92 & $\begin{array}{l}\text { Terima Ho } \\
(\mathrm{P}: 0,1310)\end{array}$ \\
\hline$\alpha 4^{*}=\alpha 4^{*}$ & $\alpha i^{*} \neq \alpha 4$ *” & $\begin{array}{l}\text { Alokasi optimum } \\
\text { pestisida }\end{array}$ & 609,28 & 6,85 & 3,92 & $\begin{array}{l}\text { Tolak Ho } \\
(\mathrm{P}: 0,0000)\end{array}$ \\
\hline
\end{tabular}

Sumber: Hasil olah data, 2017

Keterangan:

1. Angka dalam ( ) adalah probability value

2. a) : Nyata pada derajat kepercayaan $99 \%(\alpha=0,01)$

b) : Nyata pada derajat kepercayaan $95 \%(\alpha=0,05)$

c) : Nyata pada derajat kepercayaan $90 \%(\alpha=0,10)$

Temuan penelitian ini menunjukan bahwa usaha persuteraan alam di Kabupaten Enrekang belum mencapai keuntungan maksimum. Dengan kata lain secara keseluruhan alokasi input-input varabel belum dapat mencapai optimal. Dari basil pengujian parsial tampak bahwa dari masing-masing input variabel bibit dan pestisida, hipotesis nol ditolak pada derajat kesalahan $\alpha=0,01$, yang artinya alokasi penggunaan bibit dan pestisida belum optimal. Pada pengujian keuntungan maksimum dinyatakan jika ada salah satu Ho ditolak maka usaha persuteraan alam hibrida tidak dapat mencapai keuntungan maksimum jangka pendek.

Hal demikian dihadapkan fenomena penggunaan bibit pada daerah penelitian cenderung belum optimal sedangkan penggunaan pestisida kurang efektif mengingat dalam penggunaan pestisida tidak mempertimbangkan ada atau tidak adanya hama penyakit. Para petani dalam menggunakan pestisida berdasarkan faktor kebiasaan mereka dalam memberikan pestisida terhadap tanaman murbei sehingga terjadi pemberian pestisida yang tidak perlu pada tanaman ulat yang dimilikinya. Oleh karena itu dengan pembinaan teknis penggunaan mutu dan jumlah bibit yang sesuai dengan standard teknis serta penggunaan pestisida yang efektif maka proses produksi yang diharapkan akan bekerja pada kondisi rasional (decreasing return to scale) (Tahir dan Hasan, 2018; Munarfah dan Hasan, 2012).

Hal demikian menunjukkan bahwa biaya marginal (Marginal Cost/MC) dari masingmasing input variabel tersebut belum sama dengan penerimaan marginalnya (Marginal Revenue/MR) sehingga keuntungan maksimal tidak dapat tercapai. Sedangkan pengujian alokasi input variabel tenaga kerja dan pupuk, 
hipotesis diterima pada derajat kesalahan $\alpha=0,01$ yang artinya alokasi penggunaan input variabel tenaga kerja dan pupuk telah mencapai optimum.

Skala usaha (returns to scale) menggambarkan respons dari suatu output terhadap perubahan proporsional dari input. Dalam kasus fungsi keuntungan Cobb-Douglas, Lau (1972) menyatakan bahwa kondisi skala ekonomi usaha dapat diketahui dengan menguji berapa nilai. Jika nilainya $=1$ maka usaha pada kondisi constant returns to scale. Jika nilainya < 1 decreasing returns to scale dan jika nilainya > 1 increasing return to scale. Hasil pengujian kondisi skala usaha dapat dilihat pada Tabel 2 berikut ini.

Tabel 2. Kondisi penggunaan parameter pengujian tingkat skala usaha

\begin{tabular}{|c|c|c|c|c|c|}
\hline \multirow{2}{*}{ Nilai Dugaan } & \multirow{2}{*}{ Hipotesis } & \multirow{2}{*}{ F Hitung } & \multicolumn{2}{|c|}{ F Tabel } & \multirow{2}{*}{ Keputusan } \\
\hline & & & $\mathbf{0 , 0 1}$ & 0,05 & \\
\hline 1,0686 & $\begin{array}{l}\text { Но: } \beta 1^{*}+\beta 2^{*}=1 \\
\text { На: } \beta 1^{*}+\beta 2^{*} \neq 1\end{array}$ & 8,762 & 6,85 & 3,92 & $\begin{array}{l}\text { Tolak Ho } \\
(\mathrm{P}: 0,0016)\end{array}$ \\
\hline
\end{tabular}

Sumber: Hasil olah data, 2017

Hasil pengujian skala usaha sebagaimana tampak pada Tabel 8 menunjukan bahwa nilai $\mathrm{F}$ hitung lebih besar dari nilai $\mathrm{F}$ tabel pada derajat kepercayaan 99 persen $(\alpha=0,01)$ dengan $p$-value 0,0016 sehingga hipotesis nol ditolak, berarti skala usaha pada usaha persuteraan alam di Propinsi Sulawesi Selatan tidak berada pada kondisi constant returns to scale. Dilihat dari nilai dugaan $\Sigma \beta j^{*}=1,0297$ dan lebih besar dari satu menunjukkan bahwa kondisi skala usaha produksi pada usaha persuteraan alam rata-rata berada keadaan increasing return to scale (IRTS). Keadaan ini dapat terjadi mengingat kualitas tenaga kerja maupun mutu dari sarana produksi seperti penggunaan bibit yang belum optimal, pestisida yang tidak efektif cara pemupukan yang kurang tepat. Hal ini menunjukkan bahwa apabila seluruh input diubah satu unit, menyebabkan perubahan tingkat keuntungan lebih dari 1 unit. Dalam hal ini misalnya input variabel dinaikan kualitasnya sebesar 10 persen, maka keuntungan usaha akan meningkat 10,68 persen. Berdasarkan hal tersebut, dapat diketahui bahwa pemanfaatan sumberdaya atau faktor produksi pada usaha persuteraan alam di Kabupaten Enrekang masih dapat ditingkatkan atau dikembangkan.

\section{SIMPULAN DAN SARAN Simpulan}

Hasil penelitian ini menunjukan bahwa skala usaha pada usaha persuteraan alam di Propinsi Sulawesi Selatan tidak berada pada kondisi constant returns to scale, sehingga hal tersebut berarti bahwa pemanfaatan sumberdaya atau faktor produksi pada usaha persuteraan alam di Kabupaten Enrekang masih dapat ditingkatkan atau dikembangkan.

\section{Saran}

Mengingat tingkat keuntungan yang tercapai produsen tidak saja ditentukan oleh besar kecilnya produksi melainkan juga oleh hargaharga input dan output maka pemerintah kabupaten seharusnya mengambil peran dalam pengendalian kelancaran distribusi sarana produksi khususnya ketersediaan pupuk dan kestabilan harga input lainnya. Bila dikaitkan dengan kondisi return to scale, hasil studi ini menunjukan bahwa usaha persuteraan alam di daerah penelitian berada pada kondisi increasing return to scale (kenaikan hasil yang meningkat). Oleh karena itu pemerintah melalui institusi dinas-dinas terkait lebih intensif melakukan pembinaan teknis terhadap petani khususnya penyuluhan pertanian mengenai anjuran penggunaan faktor produksi yang lebih optimal. Pihak instansi terkait memberikan pengarahan dan penyuluhan terutama kepada petani skala besar agar dapat meningkatkan efektifitas produksinya. Hal ini dilakukan didasari pada petani besar memiliki efisiensi yang lebih rendah dibandingkan dengan petani kecil.

\section{DAFTAR RUJUKAN}

Barrett, Christopher, Michael R. Carter and C. Peter Timmer. 2010. A Century-Long Perspective on Agricultural Development. American Journal of Agricultural Economics 92 (2): 447-468.

Cypher, James M. and James L. Dietz. 2008. The Process of Economic Development. Oxon: Routledge.

Diao, Xinshen, Peter Hazell, Danielle Resnick and James Thurlow. 2006. The Role of Agriculture in Development: Implications for Sub-Saharan Africa. 
DSGD Discussion Paper No. 29, IFPRI, Washington D.C.

Fei, J.C. and Ranis, G., 1961. A Theory of Economic Development. American Economic Review 514, 533-65.

Hasan, Muhammad. 2012. Keunggulan Komparatif Sektor Pertanian. Jurnal Ekonomi Pembangunan dan Pertanian, Volume 1 Nomor 1 2012. Universitas Negeri Makassar.

Hasan, Muhammad. 2013. Investasi Pemerintah dan Swasta Pada Sektor Pertanian sebagai Input dalam Formulasi Kebijakan Publik di Bidang Ekonomi. Jurnal Birokrasi, Volume 1 Nomor 1 2013, 51-58. Universitas Negeri Makassar.

Hasan, Muhammad. 2013. Determinan Investasi Pada Sektor Pertanian. Jurnal Ekonomi Pembangunan dan Pertanian, Volume 3 Nomor 1 2013, 62-83. Universitas Negeri Makassar.

Hasan, Muhammad. 2014. Keunggulan Kompetitif Komoditi Kakao. Jurnal Economix, Volume 2 Nomor 1 Juni 2014 : 11-17. Universitas Negeri Makassar.

Hasan, Muhammad, dan Azis, Muhammad. 2018. Pembangunan Ekonomi \& Pemberdayaan Masyarakat: Strategi Pembangunan Manusia dalam Perspektif Ekonomi Lokal. Makassar: CV. Nur Lina Bekerjasama dengan Pustaka Taman Ilmu.

Hirschman, A.O., 1958. The Strategy of Economic Development in Developing Countries, Yale University Press, New Haven, Connecticut, USA.

Johnston, B.F. and Mellor, J.W., 1961. The role of agriculture in economic development. American Economic Review 51, 566-93.

Hirschman, A.O., 1958. The Strategy of Economic Development in Developing Countries. Yale University Press, New Haven, Connecticut, USA.

Johnston, B.F. and Mellor, J.W. 1961. The Role of Agriculture in Economic Development. American Economic Review 51, 566-93.

Jorgenson, D.G., 1961. The Development of a Dual Economy. Economic Journal 71, 309-34.
Kuznets, Simon. 1966. Modern Economic Growth: Rate, Structure, and Spread. New Haven: Yale University Press.

Lewis, W.A., 1954. Economic Development with Unlimited Supplies of Labour. Manchester School of Economics 20, 139-91.

Munarfah, Andi, dan Hasan, Muhammad. 2009. Metode Penelitian. Jakarta: CV. Pratika Aksara Semesta.

Munarfah, Andi, dan Hasan, Muhammad. 2012. Model Pengembangan Sumberdaya Ekonomi Berbasis Kekuatan Lokal (Studi Kasus Pada Usaha Persuteraan Alam di Provinsi Sulawesi Selatan). Hasil Penelitian Hibah Strategis Nasional DP2M Dikti Tahun 2012.

Rosenstein-Rodan, P.N. 1943. Problems of Industrialization of Eastern and SouthEastern Europe. Economic Journal 53, 202-11.

Schultz, Theodore William. 1964. Transforming Traditional Agriculture. New Haven: Yale University Press.

Scitovsky, T., 1954. Two Concepts of External Economies. Journal of Political Economy 62, 143-51.

Tahir, Thamrin, and Hasan, Muhammad. 2010. Analisis Prilaku Sosial Ekonomi Petani di Desa Lambatorang Kecamatan Bantimurung Kabupaten Maros (Tinjauan terhadap Aspek Produksi dan Pendapatan). Hasil Penelitian PNBP Fakultas Ekonomi Universitas Negeri Makassar.

Tahir, Thamrin, and Hasan, Muhammad. 2018. Poverty's Characteristics and its Reduction Strategies: A Case Study. European Research Studies Journal, XXI (2). pp. 426-440. 